\title{
Wheat Physiological Parameters under Long Term Fertilizer and Manure Application in a Vertisol
}

\author{
Jyoti Bangre $^{1^{*} \text {, A. K. Dwivedi }}{ }^{1}$, M. Mohanty ${ }^{2}$, B. S. Dwivedi ${ }^{1}$, S. K. Dwivedi ${ }^{1}$, \\ N. K. Sinha ${ }^{2}$, H. L. Sharma ${ }^{1}$, Subhash ${ }^{2}$ and Shishram Jakhar ${ }^{1}$ \\ ${ }^{I}$ Department of Soil Science and Agricultural Chemistry, Jawaharlal Nehru Krishi Vishwa \\ Vidyalaya, Jabalpur (M.P) 482004, India \\ ${ }^{2}$ Division of Soil Physics, ICAR-Indian Institute of Soil Science, Bhopal (M.P.) 462038, India \\ *Corresponding author
}

\section{A B S T R A C T}

\section{Keywords \\ Wheat, Leaf area index, Leaf area duration, Relative growth rate, Long term fertilizer application}

Article Info

Accepted:

22 June 2020

Available Online:

10 July 2020
A field experiment was conducted in an on going Long-Term Fertilizer Experiment during 2017-18 and 2018-19 at the Research Farm, College of Agriculture, Jawaharlal Nehru Krishi Vishwa Vidyalaya, Jabalpur to study the effect of long-term fertilizer application on performance of wheat crop and soil properties. The experiment was conducted in a randomized block design with ten treatments in four replications. The treatments comprised were $50 \%$ NPK, $100 \%$ NPK, $150 \%$ NPK, $100 \%$ NPK + Hand weeding, $100 \%$ NPK + Zn, $100 \%$ NP, $100 \%$ N, 100\% NPK + FYM, 100\% NPK-S and Control. The wheat crop (cv. GW-366) was grown with recommended nutrient dose of 120:80:40 ( $\mathrm{N}: \mathrm{P}_{2} \mathrm{O}_{5}$ : $\mathrm{K}_{2} \mathrm{O}$ ) in rabi season. The leaf area index, leaf area duration and relative growth rate was determined at important growth stages viz., crown root initiation, tillering stage, flowering stage, milking stage and at dough stage. The grain and straw yield were recorded at crop harvest. The results revealed that, the wheat responded positively to the balanced nutrition as compared to no fertilization and imbalanced fertilization. The wheat physiology and crop yield showed significant and positive response to $100 \%$ NPK + FYM, recommended NPK and super optimal NPK application. The stage wise physiological response of wheat was also observed irrespective of the treatments.

\section{Introduction}

Wheat (Triticum aestivum L.) is one of the most important cereal crops globally and is a staple food for about one third of the world's population. It occupies second position both in terms of area and production in the world (Evans and Wardlaw, 1996). It is cultivated over an area of 29.86 million hectares with an annual production of 94.88 million tonnes and productivity of $3.18 \mathrm{Mt} / \mathrm{ha}$ in India, whereas in Madhya Pradesh, it is cultivated in 4.89 thousand hectares of land with an annual production of 12.69 million tonnes and productivity of $2.36 \mathrm{Mt} / \mathrm{ha}$ (Krishnan et al., 2019).

Long Term Fertilizer Experiment (LTFE) plays an important role in understanding the complex interactions between soil, plant and 
environmental continuum (Dwivedi and Dwivedi, 2015). The LTFE provides valuable inputs for making the agriculture sustainable where the fertilizer application is very high and cropping is intensive (Singh and Wanjari, 2013). At the beginning of the LTFE's, they were aimed for optimum production with fertilizer application and study the ill effects on soil (Dwivedi et al., 2018).

The aim of starting the LTFE was to study the impact of the continuous addition of fertilizer and organic manure for sustainability of high production farming (Tomar and Dwivedi, 2007; Dwivedi et al., 2007).The continuous and imbalanced fertilizer application to the soils resulting in deterioration of soil health especially due to imbalanced fertilizer application and continuous application of inorganic fertilizer without organic inputs (Rajput et al., 2016; Singh and Wanjari, 2018). However, the combined application of manures and chemical fertilizers has shown beneficial effects on soil physico-chemical and biological properties, and crop yields (Dwivedi et al., 2016). The changes in soil properties are reflected in crop economic yield through physiological parameters in a growing crop.

The physiological parameters ultimately show positive influence on cell size, leaf area and ultimately photosynthetic activity (Rahman et al., 2000). Nutrient management offers the opportunity for increasing wheat growth, yield and its nutrient components (Bangre 2018; Dotaniya et al., 2020). Appropriate fertilizer application rates and methods enhance the crop physiology and it reflects in to the crop yield. Increase in net accumulation rate is attributed to increased photosynthetic capacity of the leaves with improved nutrition of the plants.

The Relative Growth Rate (RGR) improve with the increasing soil $\mathrm{N}$ availability for plant (Warraich et al., 2002). The present field experiment was carried out to study the response of long-term fertilizer application on physiological parameters and wheat productivity in a Vertisol of central India. The integrated use of organic manuring and inorganic fertilizers has maintaining favourable ecological conditions and helps to restore and sustain fertility and crop productivity on long-term basis (Kumar \& Dey, 2007).

\section{Materials and Methods}

Experimental site, climate and soil characteristics

Present study was conducted in an ongoing scheme All India Coordinated Research Project (AICRP) on Long Term Fertilizers Experiment (LTFE) of Indian Council of Agricultural Research (ICAR). The LTFE is laid out on a permanent site at the Experimental field Department of Soil Science and Agricultural Chemistry, Jawaharlal Nehru Krishi Vishwa Vidyalaya, Jabalpur (M.P.). The experimental site is located in 'Kymore Plateau and Satpura Hills' agro climatic region of M.P. It falls on $23.9^{\circ}$ $\mathrm{N}$ latitude and $79.6^{\circ} \mathrm{E}$ longitudes with an altitude of $411.8 \mathrm{~m}$ above the mean sea level.

Jabalpur is situated in the semi-arid region having sub-tropical climate with hot dry summer, and cold winter. The average rainfall is about $1350 \mathrm{~mm}$, which is mainly distributed from mid-June to October. The maximum and minimum temperature ranges between $35.1{ }^{\circ} \mathrm{C}$ and $5.3^{\circ} \mathrm{C}$. The average annual relative humidity is $62-70 \%$. The experiment was started in 1972; the cropping sequence being followed is soybean (Kharif) and wheat (Rabi). The soil of the experimental field is medium black belonging to Kheri series of fine montmorillonitic hyperthermic family of Typic Haplustert. 


\section{Treatments detail}

The experiment was started from since 1972 with 10 different treatments. The details of the treatments are presented in Table 2. The $100 \%$ optimal NPK doses based on initial (1972) soil test values was 120:80:40 (N: $\left.\mathrm{P}_{2} \mathrm{O}_{5}: \mathrm{K}_{2} \mathrm{O}\right)$ for wheat. Nitrogen was applied through urea, phosphorus through single super phosphate and potassium was applied through murate of potash.

The farm yard manure (FYM) treatment was applied @ 5-ton $\mathrm{ha}^{-1}$ year ${ }^{-1}$ to soybean crop only. Due to build-up of $\mathrm{Zn}$ content in soil, the application of $\mathrm{Zn}$ as $\mathrm{ZnSO}_{4} @ 20 \mathrm{Kg} \mathrm{ha}^{-1}$ in alternate year to wheat crop was discontinued since, 1987. The treatments comprised were $50 \%$ NPK, $100 \%$ NPK, $150 \%$ NPK, $100 \%$ NPK + Hand weeding, $100 \%$ NPK + Zn, $100 \%$ NP, $100 \%$ N, $100 \%$ NPK + FYM, 100\% NPK-S and Control.

\section{Physiological observations}

The wheat crop (cv. GW-366) was grown with nutrient dose of 120:80:40 (N: P2O5:K2O) in rabi season of 2017-18 and 2018-19. The crop was sown in last week of November and first week of December in rabi season of 2017-18 and 2018-19, respectively. Similarly, the crop was harvested at physiological maturity in April.

The periodic wheat physiological parameters such as leaf area index (LAI), leaf area duration (LAD) and relative growth rate (RGR) were determined by standard methods (Watson, 1952). The physiological parameters were determined at crown root initiation (CRI), tillering stage (TS), flowering stage (FS), milking stage (MS) and at dough stage (DS). The field experiment was laid in a randomized block design (RBD) with ten treatments in four replications.

\section{Statistical analysis}

The data found was compiled and analysed for its significance $(p=0.05)$ by statistical procedure for randomized block design as outlined by Gomez and Gomez (1984).

\section{Results and Discussion}

The physiological parameters of wheat viz. leaf area index, leaf area duration and relative growth rate, were studied during important growth stages and yield was recorded at harvesting of the crop.

\section{Leaf Area Index}

The pooled data of leaf area index (LAI) of wheat differed significantly under the influence of various treatments under long term fertilizer application during the various crop growth stages of wheat viz., crown root initiation (CRI), tillering (TS), flowering (FS), milking (MS) and dough stage (DS). The highest LAI of at CRI, TS, FS, MS and DS, respectively was observed under the treatment involving application of organic manure along with inorganic fertilizer i.e. treatment $\mathrm{T}_{8} 100 \% \mathrm{NPK}+\mathrm{FYM}(0.67,1.93$, $3.71,3.39$ and 1.82). The data with respect to the LAI at various growth stages clearly showed that maximum values was found with higher doses of fertilizer followed by imbalanced, suboptimal fertilizer and balanced fertilizer application throughout the growth period. The leaf area was increased as growth of the plant proceeded from early to maturity. The lower LAI was found at FS and increased at MS but found declined further at DS. It has also been observed that the LAI was found significantly influenced under various treatments under study irrespective of the growth stages of wheat. The highest LAI was observed during flowering stage to milking stage irrespective of the treatment applied. The leaf area index expresses the 
ratio of leaf surface (one sided green leaf area) to the ground area occupied by the crop. It also describes the functional size of assimilatory apparatus of other growth parameters (Watson, 1947). The assimilatory surface area of crop stands and its increase has a direct bearing on the amount of solar energy intercepted by canopy and represented the productive capacity of a crop. Yagoub et al., (2012) showed an increase in LAI in
$100 \%$ NPK + FYM as compared to control. The balanced use of fertilizer is also known for significantly increasing LAI (Singh and Sharma, 2014). Application of organic manure along with chemical fertilizer increased leaf area index as compared with inorganic fertilizer alone. The maximum leaf area was expressed (30, 45 and 60 DAS) in treatment $100 \%$ NPK + FYM by Verma et al., (2017).

Table.1 Effect of long-term application of fertilizer and manure on leaf area index and leaf area duration in wheat

\begin{tabular}{|c|c|c|c|c|c|c|c|c|c|}
\hline \multirow[t]{2}{*}{ Treatment } & \multicolumn{5}{|c|}{ Leaf area index } & \multicolumn{4}{|c|}{ Leaf area duration $\left(\mathrm{cm}^{2}\right.$ days $)$} \\
\hline & CRI & $\mathbf{T S}$ & FS & MS & DS & CRI & TS & FS & DS \\
\hline $\mathrm{T}_{1}-50 \% \mathrm{NPK}$ & 0.42 & 1.45 & 2.47 & 2.44 & 1.24 & 53.2 & 112.0 & 204.8 & 158.6 \\
\hline $\mathrm{T}_{2-} \mathbf{1 0 0 \%} \mathrm{NPK}$ & 0.55 & 1.68 & 3.01 & 2.92 & 1.54 & 64.8 & 127.5 & 241.0 & 187.7 \\
\hline $\mathrm{T}_{3-} \mathbf{1 5 0 \%} \mathrm{NPK}$ & 0.66 & 1.92 & 3.68 & 3.36 & 1.81 & 74.2 & 143.2 & 275.1 & 217.6 \\
\hline $\mathrm{T}_{4}-100 \% \mathrm{NPK}+\mathrm{HW}$ & 0.52 & 1.60 & 2.95 & 2.87 & 1.52 & 62.9 & 125.4 & 236.3 & 187.1 \\
\hline$T_{5}-100 \% \mathrm{NPK}+\mathrm{Zn}$ & 0.53 & 1.62 & 2.97 & 2.88 & 1.53 & 63.6 & 126.0 & 238.0 & 187.2 \\
\hline $\mathrm{T}_{6}-100 \% \mathrm{NP}$ & 0.45 & 1.50 & 2.46 & 2.53 & 1.34 & 57.1 & 110.3 & 194.0 & 158.5 \\
\hline $\mathrm{T}_{7}-100 \% \mathrm{~N}$ & 0.32 & 1.20 & 1.92 & 1.87 & 0.94 & 45.0 & 96.1 & 160.5 & 127.9 \\
\hline $\mathrm{T}_{8^{-}} \mathbf{1 0 0 \%} \mathrm{NPK}+\mathrm{FYM}$ & 0.67 & 1.93 & 3.71 & 3.39 & 1.82 & 75.0 & 147.8 & 280.6 & 219.3 \\
\hline$T_{9-} 100 \%$ NPK-S & 0.49 & 1.55 & 2.91 & 2.83 & 1.49 & 62.6 & 118.1 & 231.9 & 180.3 \\
\hline $\mathbf{T}_{10^{-}}$Control & 0.27 & 0.79 & 1.88 & 1.76 & 0.91 & 43.6 & 94.1 & 153.3 & 117.7 \\
\hline $\mathrm{SEm} \pm$ & 0.03 & 0.06 & 0.16 & 0.12 & 0.06 & 2.39 & 5.09 & 9.38 & 9.38 \\
\hline $\operatorname{CD}(p=0.05)$ & 0.08 & 0.17 & 0.47 & 0.35 & 0.18 & 6.93 & 14.75 & 27.21 & 27.21 \\
\hline
\end{tabular}

Table.2 Effect of long-term application of fertilizer and manure on relative growth rate in wheat

\begin{tabular}{|c|c|c|c|c|}
\hline \multirow[t]{2}{*}{ Treatments } & \multicolumn{4}{|c|}{ Relative growth rate $\left(\mathrm{g}^{-1} \mathrm{~g}^{-1}\right.$ day $)$} \\
\hline & CRI & TS & FS & DS \\
\hline $\mathrm{T}_{1}-50 \% \mathrm{NPK}$ & 0.017 & 0.020 & 0.028 & 0.004 \\
\hline$T_{2}-100 \%$ NPK & 0.025 & 0.030 & 0.039 & 0.008 \\
\hline$T_{3}-150 \%$ NPK & 0.032 & 0.036 & 0.047 & 0.010 \\
\hline $\mathrm{T}_{4}-100 \% \mathrm{NPK}+\mathrm{HW}$ & 0.022 & 0.025 & 0.035 & 0.006 \\
\hline $\mathrm{T}_{5^{-}} \mathbf{1 0 0 \%} \mathrm{NPK}+\mathrm{Zn}$ & 0.023 & 0.026 & 0.037 & 0.007 \\
\hline$T_{6}=100 \% \mathrm{NP}$ & 0.021 & 0.023 & 0.033 & 0.005 \\
\hline $\mathrm{T}_{7}-100 \% \mathrm{~N}$ & 0.011 & 0.015 & 0.019 & 0.003 \\
\hline $\mathrm{T}_{8^{-}} \mathbf{1 0 0 \%} \mathrm{NPK}+\mathrm{FYM}$ & 0.034 & 0.038 & 0.048 & 0.011 \\
\hline$T_{9-}-100 \%$ NPK-S & 0.021 & 0.024 & 0.034 & 0.006 \\
\hline $\mathbf{T}_{10^{-}}$Control & 0.011 & 0.013 & 0.017 & 0.002 \\
\hline $\mathrm{SEm} \pm$ & 0.027 & 0.001 & 0.001 & 0.002 \\
\hline $\operatorname{CD}(p=0.05)$ & 0.106 & 0.003 & 0.004 & 0.005 \\
\hline
\end{tabular}


Table.3 Grain and straw yield of wheat under different treatments given below

\begin{tabular}{|c|c|c|c|c|c|c|}
\hline \multirow[t]{2}{*}{ Treatments } & \multicolumn{3}{|c|}{ Grain yield (t ha ${ }^{-1}$ ) } & \multicolumn{3}{|c|}{ Straw yield $\left(\mathrm{t} \mathrm{ha} \mathbf{p}^{-1}\right)$} \\
\hline & 2017 & 2018 & Mean & 2017 & 2018 & Mean \\
\hline $\mathbf{T}_{1}-50 \%$ NPK & 4.30 & 4.19 & 4.24 & 5.38 & 5.56 & 5.47 \\
\hline $\mathrm{T}_{2-} \mathbf{1 0 0 \%} \mathrm{NPK}$ & 5.38 & 5.23 & 5.30 & 5.82 & 6.02 & 5.92 \\
\hline $\mathrm{T}_{3-} \mathbf{1 5 0 \%} \mathrm{NPK}$ & 5.99 & 6.03 & 6.01 & 6.12 & 6.31 & 6.22 \\
\hline $\mathrm{T}_{4}-100 \% \mathrm{NPK}+\mathrm{HW}$ & 5.33 & 5.25 & 5.29 & 5.90 & 6.11 & 6.01 \\
\hline $\mathrm{T}_{5^{-}} \mathbf{1 0 0 \%} \mathrm{NPK}+\mathrm{Zn}$ & 5.37 & 5.26 & 5.32 & 6.11 & 6.26 & 6.19 \\
\hline $\mathrm{T}_{6}-100 \% \mathrm{NP}$ & 4.38 & 4.15 & 4.26 & 5.62 & 5.79 & 5.71 \\
\hline $\mathrm{T}_{7}-100 \% \mathrm{~N}$ & 1.78 & 1.78 & 1.78 & 5.26 & 5.44 & 5.35 \\
\hline $\mathrm{T}_{8}-100 \% \mathrm{NPK}+\mathrm{FYM}$ & 6.18 & 6.14 & 6.16 & 6.46 & 6.68 & 6.57 \\
\hline$T_{9-} 100 \%$ NPK-S & 4.58 & 4.54 & 4.56 & 5.73 & 5.98 & 5.86 \\
\hline $\mathbf{T}_{10^{-}}$Control & 1.45 & 1.36 & 1.41 & 3.87 & 4.02 & 3.95 \\
\hline $\mathrm{SEm} \pm$ & 0.26 & 0.24 & 0.24 & 0.32 & 0.36 & 0.57 \\
\hline $\operatorname{CD}(p=0.05)$ & 0.76 & 0.71 & 0.91 & 0.93 & 1.05 & 1.22 \\
\hline
\end{tabular}

Fig.1 Meteorological observations during experimental period

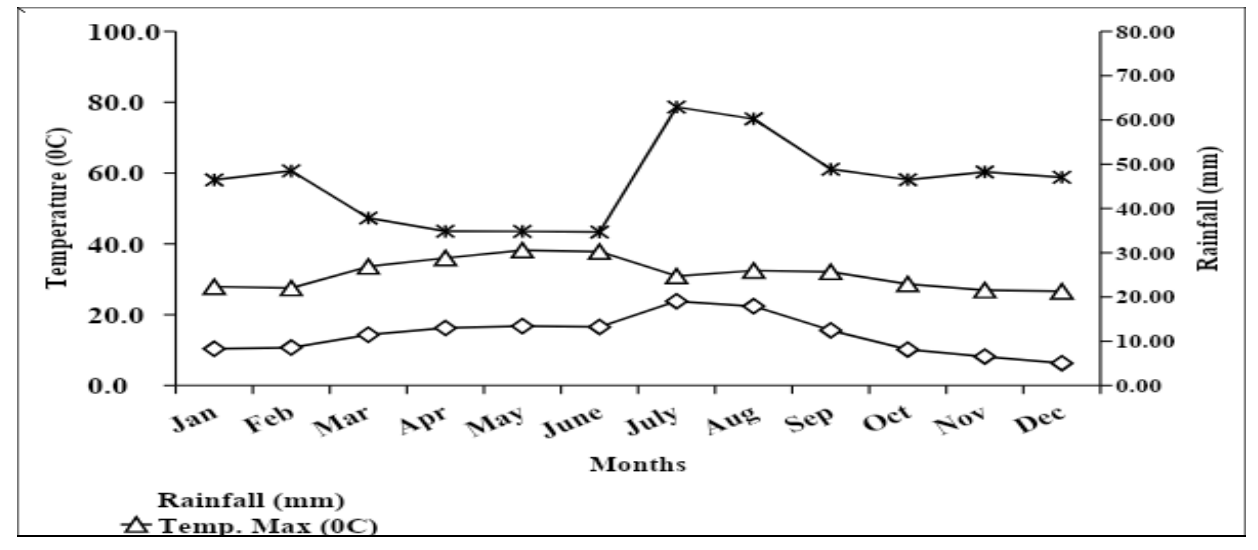

Fig.2 Effect of long-term application of fertilizer and manure on Leaf area index

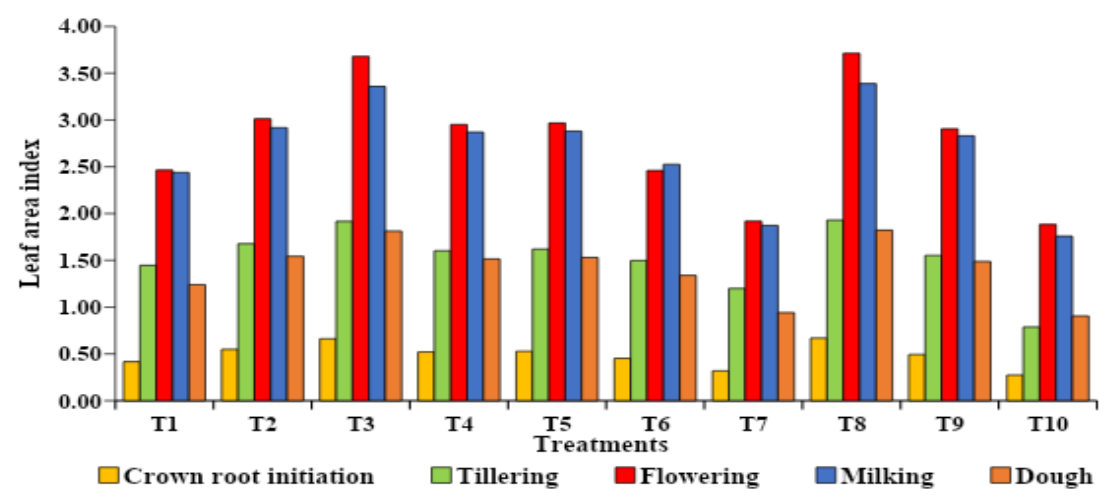


Fig.3 Effect of long-term application of fertilizer and manure on leaf area duration $\left(\mathrm{cm}^{2}\right.$ days $)$ of wheat

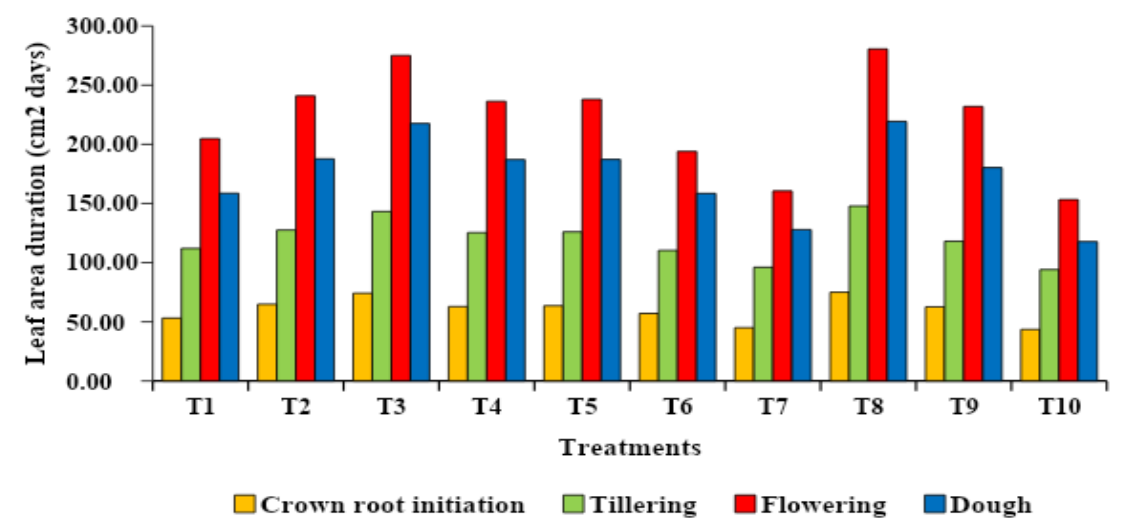

Fig.4 Effect of long-term application of fertilizer and manure on relative growth rate $\left(\mathrm{g}^{-1} \mathrm{~g}^{-1}\right.$ day) of wheat

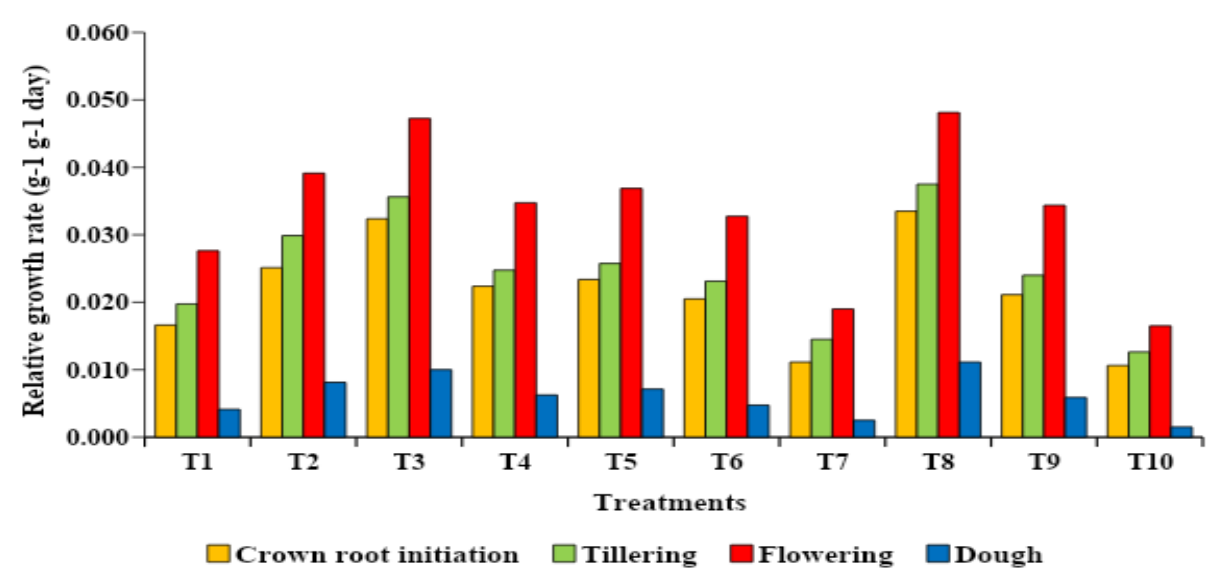

Fig.5 Grain yield and straw yield of wheat under various treatments

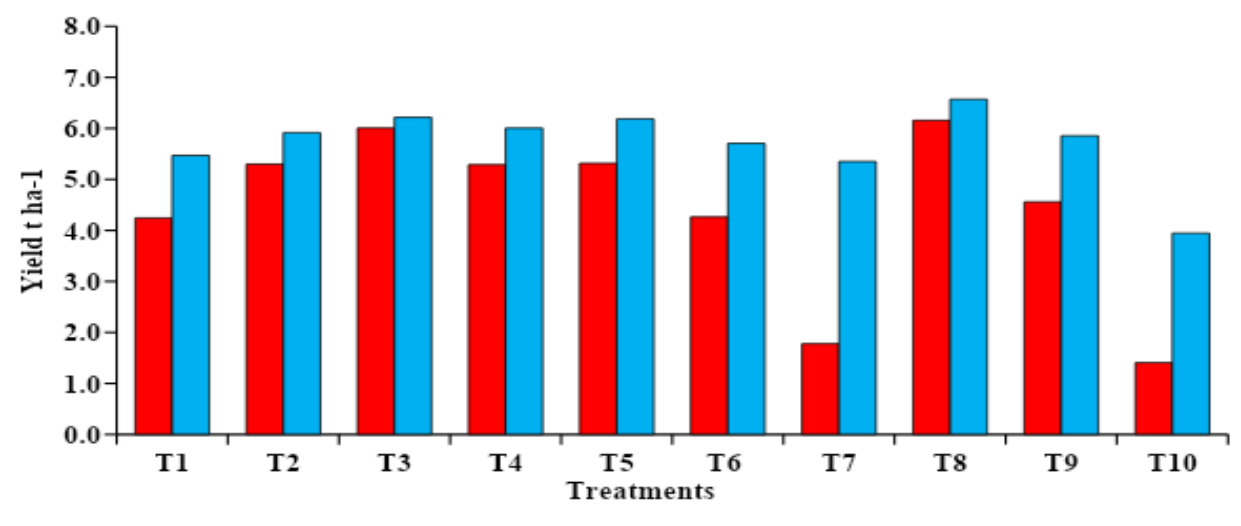

Grain yield

$\square$ Straw yield 


\section{Leaf area duration}

The LAD of wheat was found highest under the treatment receiving $100 \%$ NPK + FYM $\left(75,147.8,280.6,219.3 \mathrm{~cm}^{2}\right.$ days) followed by super optimal dose of fertilizer $150 \%$ NPK (74.2, 143.2, 275.1 and $217.6 \mathrm{~cm}^{2}$ days) and recommended dose of chemical fertilizers (100\% NPK). The lower LAD values were found under sole $\mathrm{N}$ application $100 \% \mathrm{~N}$ (45, $96.1,160.5,127.9 \mathrm{~cm}^{2}$ days) and under unfertilized control (43.6, 94.1, 153.3, 117.7 $\mathrm{cm}^{2}$ days). The leaf area duration was increased with the growth of the plant and again declined i.e. early to flowering and flowering to maturity. Hence, the lower LAD values were found at tillering stage and increased till flowering stage but was found declined at dough stage (Peltonen-Sainio et al., 1997). Bandopadhyay et al., (2010), Kumar et al., (2012) and Shaukat et al., (2020) reported similar findings with respect to the LAD. The LAD expresses the magnitude and persistence of leaf area and leafiness during period of crop growth. Similarly, LAD may express the ability of plant to produce and maintain leaf area and efficiency to assimilation during growing season which is described as the leaf area duration (Watson, 1947) and it is also called the photosynthesis potential (Kvet, 1978). The LAD is significantly dependent on the maintenance of photo synthetically active assimilatory surface area. These processes are influenced by both genetic as well as environmental factor especially nutrient management (Singh and Agarwal, 2001).

\section{Relative Growth Rate}

The relative growth rate (RGR) was found higher with optimal dose of fertilizer along with organic manure at various growth stages (CRI, TS, FS and DS) followed by super optimal dose of fertilizer $(0.032,0.036,0.047$ and $0.010 \mathrm{~g} \mathrm{~g}^{-1} \mathrm{~g}^{-1}$ day). The lowest RGR content in control $(0.011,0.013,0.017$ and $0.002 \mathrm{~g} \mathrm{~g}^{-1} \mathrm{~g}^{-1}$ day) and highest in value was observed in $100 \%$ NPK + FYM $(0.034,0.038$, 0.048 and $0.011 \mathrm{~g} \mathrm{~g}^{-1} \mathrm{~g}^{-1}$ day). The maximum RGR was expressed at CRI, TS, FS and DS in treatment $100 \%$ NPK + FYM. Karimi and Siddique (1991) studied the RGR of wheat in Australia and found significant differences under different nutrition. Similarly, Tandale and Ubale (2007), Alam (2013), Mohanty et al., (2015) and Verma et al., (2017) observed the significantly higher growth rates in wheat under the application of higher nitrogen and combined application with organic manures in various soil types.

\section{Crop productivity}

The two-year pooled data of grain yield and straw yield of wheat showed during 2017-18 and 2018-19 is presented in table 3 and Fig 5. The grain and straw yield of wheat was significantly influenced under various nutrient management practices. The highest grain yield and straw yield was observed under the treatment $\mathrm{T} 8$ receiving combined application of 100\% NPK and FYM @ 5 t/ha (6.16 and $\left.6.57 \mathrm{t} \mathrm{ha}^{-1}\right)$ followed by T3 (6.01 and $6.22 \mathrm{t}$ $\left.\mathrm{ha}^{-1}\right)$ and T5 (5.32, $\left.6.19 \mathrm{t} \mathrm{ha}^{-1}\right)$. The grain yield and straw yield of wheat crop followed similar trend during the period of investigation. The lowest grain and straw yield were observed in unfertilized control $\left(1.41\right.$ and $\left.3.95 \mathrm{t} \mathrm{ha}^{-1}\right)$. Organic manures and inorganic fertilizers with combinations, as increased the nutrient use efficiency and improved the physical and chemical properties of soil hence making better utilization of nutrients might also be a reason towards increased yield (Singh et al., 2009). Similar results were reported by Chuan et al., (2013). Straw yield is a function of vegetative growth. The increase in growth and yield owing to the application of inorganic fertilizer may be attributed to the fact that this nutrient being important constituents of nucleotides, 
proteins, chlorophyll and enzymes, involves in various metabolic processes which have direct impact on vegetative and reproductive phase of plants. The data clearly indicated that under intensive cultivation addition of integrated application of fertilizer with FYM was found to be beneficial for maintain the fertility if the soil as well as subsequently improving the potential of soybean-wheat cropping system (Dubey \& Dwivedi, 2016). These findings confirm those of (Sharma and Singh 2011; Chuan et al., 2013).

In conclusion the wheat responded positively to the balanced nutrition as compared to no fertilization and imbalanced fertilization. The wheat physiology showed significant and positive response to $\mathrm{NPK}+\mathrm{FYM}$, recommended NPK and super optimal NPK application. The stage wise physiological response of wheat was also observed irrespective of the treatments. The impact of integrated approaches on wheat physiology were showed the maximum growth of the plant and higher productivity.

\section{References}

Alam, M.S., 2013. Growth and yield potentials of wheat as affected by management practices. African Journal of Agricultural Research, 8(47), pp.6068-6072.

Bandopadhyay Paul, Jethmlani SC, Haang HY. study of nutritional and physiology of soybean. Response of autumn cropped soybean to nitrogen. Res. Bull. Tainan. Dist. Agri. Impro. Sta. 2010; 14:71-78.

Bangre, J. and Singh B. 2018. Effect of organic manures and inorganic fertilizers on physico- chemical

properties of soil and yield of soybean grown in semi-arid Vertisol. International Journal of Chemical Studies. 6(6): 1591-1594.
Chuan, L., He, P., Jin, J., Li, S., Grant, C., Xu, X., \& Zhou, W. 2013. Estimating nutrient uptake requirements for wheat in China. Field Crops Research, 146, 96-104.

Dotaniya, C. K., D. S. Yashona, S. B. Aher, R. K. Dotaniya, M. Lata, P. S. Rajput and S. Mohbe, 2020. Crop performance and soil properties under organic nutrient management. Int. J. Curr. Microb. Appl. Sci. 9(4): 1055-1065.

Dubey, L., Dwivedi, B.S., Dwivedi, A.K., \& Thakur, R.K. 2016. Effect of long-term application of fertilizers and manure on profile distribution of various Phosphorus fractions in Vertisol. Green Farming, 7(2), 365- 370.

Dwivedi AK, Singh M, Kauraw DL, Wanjari $\mathrm{RH}$, Chauhan SS. Research bulletin on impact of fertilizer and manure use for three decades on crop productivity and sustainability and soil quality under Soybean-Wheat system on a Vertisol in Central India. IISS, 2007, 224- 235.

Dwivedi BS, Dwivedi AK, Sharma A. 2018.Effect of continuous fertilizer and manure application on productivity of soybean-wheat cropping sequence. International Conf. on sustainability of small holder agrian in developing countries changing climate Scenario, CSAUAT, Raipur held on Feb.156; 1417.

Dwivedi, A.K. and Dwivedi, B.S., 2015. Impact of long-term fertilizer management for sustainable soil health and crop productivity: Issues and challenges. Volume: 49 Research Journal, 49(3), 374.

Dwivedi, B.S., Singh, V.K., Meena, M.C., Dey, A. and Datta, S.P., 2016. Integrated nutrient management for enhancing nitrogen use efficiency. Indian J. Fertil, 12, pp.62-71.

Evans, L.T., Wardlaw, I.F., 1996. Wheat, 
Photoassimilate Distribution Plants and Crops Source-Sink Relationships. Routledge, New York, USA.

Gomez, K. and Gomez, A.A., 1984. Statistical procedure for the agriculture research. Wily and Sone.

Karimi, M.M. and Siddique, K.H.M., 1991. Crop growth and relative growth rates of old and modern wheat cultivars. Australian Journal of Agricultural Research, 42(1), 13-20.

Krishnan, P., Aggarwal, P., Mridha, N., Bajpai, V., 2019. Spatio-temporal changes in wheat crop cultivation in India. ISPRS - Int. Arch. Photogramm. Remote Sens. Spat. Inf. Sci. 42(3), 385395.

Kumar, P., Pannu, R.K. and Khokhar, S.K., 2012. Effect of organic sources of nutrition and irrigation levels on growth and yield of wheat ( $\mathrm{T}$. aestivum). Int. J. Life Sc. Bt \& Pharm. Res, 1(4), pp.178-186.

Kumar, P., \& Dey, M. M. 2007. Long-term changes in Indian food basket and nutrition. Economic and Political Weekly, 3567-3572.

Kvet, J. and Husak, S., 1978. Primary data on biomass and production estimates in typical stands of fishpond littoral plant communities. Ecol Stud Anal Synth.

Mohanty, S.K., Singh, A.K., Jat, S.L., Parihar, C.M., Pooniya, V., Sharma, S., Chaudhary, V. and Singh, B., 2015. Precision nitrogen-management practices influences growth and yield of wheat (Triticum aestivum) under conservation agriculture. Indian Journal of Agronomy, 60(4), 617-621.

Peltonen-Sainio, P., Forsman, K. and Poutala, T., 1997. Crop Management Effects on Pre-and Post-Anthesis Changes in Leaf Area Index and Leaf Area Duration and their Contribution to Grain Yield and Yield Components in Spring Cereals. Journal of Agronomy and Crop
Science, 179(1), pp.47-61.

Singh, G., Marwaha, T. S., \& Kumar, D. 2009. Effect of resourceconserving techniques on soil microbiological parameters under longterm maize (Zea mays)-wheat (Triticum aestivum) crop rotation. Indian J. Agricultural Sciences. 79(2), 94-100.

Shaukat, M., Ahmad, A., Khaliq, T. and Afzal, I., 2020. Organic and inorganic fertilization changes the phenophases of rice (Oryza sativa L.) and wheat (Triticum aestivum L.) by modulating the photosynthetic capacity of leaves. Pakistan Journal of Agricultural Sciences, 57(1).

Sharma, S. N. \& Singh R. N. 2011. Seed rate and weed management on yield and nutrient uptake of wheat (Triticum aestivum). Indian J. Agricultural Sciences 81(12), 1174-9.

Singh Muneshwar, Wanjari RH. 2013. Measures to Sustain and Restore Declined Productivity in Alfisols under LongTerm Fertiliser Experiments Indian Journal of Fertilizers.9(2):24-32.

Singh, M. and Wanjari, R.H., 2018. Longterm effect of balanced and integrated plant nutrient supply modules on crop productivity and soil health. SAARC Training Manual on Integrated Nutrient Management for Improving Soil Health and Crop Productivity. (P. Dey et al., Eds.), 50-59.

Singh, R. and Agarwal, S.K., 2001. Analysis of growth and productivity of wheat (Triticum aestivum L.) in relation to levels of FYM and nitrogen. Indian Journal of Plant Physiology, 6(3), 279283.

Tandale, M.D. and Ubale, S.S., 2007. Evaluation of growth parameters (AGR, RGR and NAR) in relation to seed yield of soybean. Internat J. Agric. Sci, 3(1), 102-106.

Tomar VS, Dwivedi AK. 2007. Long term 
effect of fertilizers and manure application on changes in soil health of vertisol in central India. Proc. National symposium on Soil Science Research: Restrospect and Prospect in the context of Environmental Quality and Food Security Kolkata during, 7-9.

Verma, P., Yadav, A.N., Kumar, V., Singh, D.P. and Saxena, A.K., 2017. Beneficial plant-microbes' interactions: biodiversity of microbes from diverse extreme environments and its impact for crop improvement. In Plant-microbe interactions in agro-ecological perspectives 543-580. Springer, Singapore.

Warraich, E.A., Basra, S.M.A., Ahmad, N., Ahmed, R. and Aftab, M.U.H.A.M.M.A.D., 2002. Effect of nitrogen on grain quality and vigour in wheat (Triticum aestivum L.). International Journal of Agriculture and Biology, 4(4), 517-520.

Watson, D.J. 1947. Comparative physiological studies on the growth of field crops: I. Variation in net assimilation rate and leaf area between species and varieties, and within and between years. Annals of botany, 11(41)41-76.

Watson, D.J., 1952. The physiological basis of variation in yield. In Advances in agronomy (4)101-145.

Yagoub, S.O., Elkhalil, A.E. and Balasio, E.D., 2012. Effect of different watering regimes on growth of two wheat (Triticum aestivum L.) cultivars at high terraces of North Sudan. International Journal of Agri Science, 2(8) 684-695.

\section{How to cite this article:}

Jyoti Bangre, A. K. Dwivedi, M. Mohanty, B. S. Dwivedi, S. K. Dwivedi, N. K. Sinha, H. L. Sharma, Subhash and Shishram Jakhar. 2020. Wheat Physiological Parameters under Long Term Fertilizer and Manure Application in a Vertisol. Int.J.Curr.Microbiol.App.Sci. 9(07): 3511-3520. doi: https://doi.org/10.20546/ijcmas.2020.907.410 